\title{
A estranha carreira do imigrante ilegal: restrições à imigração e política de deportação nos Estados Unidos, 1921-1965*
}

\author{
Mae Ngai**
}

A lei Johnson-Reed de Imigração, de 1924, estabeleceu, pela primeira vez, restrições numéricas, tornando a imigração ilegal um problema central na aplicação da legislação sobre imigração nos Estados Unidos. Este artigo examina o advento da imigração ilegal como um fenômeno de massa e o desenvolvimento de políticas legais e administrativas voltadas para identificação, prisão e deportação de estrangeiros, bem como as reformas que habilitaram alguns estrangeiros ilegais a legalizarem sua situação. Ele examina a situação dos imigrantes ilegais provenientes da Europa e do México e como as políticas em relação a cada grupo divergiam, produzindo conseqüências distintas no curto e longo prazo em termos do estatuto racial, da condição diante da lei e da legitimidade social de cada um. O artigo defende que essas trajetórias racializadas não resultaram inteiramente do racismo existente, mas foram geradas pelas distinções administrativas e legais entre os estrangeiros criminosos e os que cruzavam

\footnotetext{
*Artigo recebido em março de 2008 e aprovado para publicação em maio de 2008. Uma versão mais completa desse artigo inicialmente apareceu no jornal Law and History Review, v. 21, n. 3, Spring, 2003. Uma nota sobre a nomenclatura e organização burocrática: o Congresso criou o Bureau de Imigração como parte do Departamento de Comércio e Trabalho em 1991 (Departamento do Trabalho em 1913). O Serviço de Imigração era o braço operacional do Bureau; a Guarda de Fronteira era uma divisão do Serviço (de Imigração). Em 1940 o Bureau de Imigração e o Bureau de Naturalização se fundiram para formar o Serviço de Imigração e Naturalização (sigla INS, em inglês). Em 1940 o Congresso colocou o INS sob o Departamento de Justiça.

** Professora de História da Columbia University. E-mail: mn53@columbia.edu.
} 
a fronteira de forma clandestina que, de modo seletivo, produziram e reverteram (?) a condição de estrangeiros ilegais (?).

Palavras-chave: Imigração - Deportação - Fronteira

The strange career of the illegal alien: immigration restriction and deportation policy in the United States, 1921-1965

The United States Johnson-Reed Immigration Act of 1924 established numerical restrictions for the first time, which made illegal immigration the central problem of U.S. immigration-law enforcement. This article examines the advent of illegal immigration as a mass phenomenon and the development of administrative-law policies to identify, apprehend, and deport illegal aliens, as well as reforms that enabled some illegal aliens to legalize their status. It examines illegal immigrants from Europe and Mexico and how policies towards each group diverged, creating different short and long-term consequences for their respective racial status, legal standing, and social legitimacy. The article argues that these racialized trajectories did not result entirely from existing racism but were in the main generated by administrative-legal distinctions between criminal aliens and unlawful-border crossers that selectively made and unmade (?) illegal aliens (?).

Keywords: Immigration - Deportation - Border

L'étrange carrière de l'immigrant illégal: restrictions à l'immigration et politique de déportation aux Etats-Unis, 1921-1965

La loi Johnson-Reed d'immigration, de 1924, a établi pour la première fois des restrictions numériques, en transformant de ce fait l'immigration illégale en un problème central en ce qui touche l'application de la législation sur l'immigration aux Etats-Unis. Cet article examine l'avènement de l'immigration illégale en tant que phénomène de masse, et le développement de politiques légales et administratives tournées vers l'identification, la prison et la déportation d'étrangers, de même que les réformes qui ont rendu possible que quelques étrangers illégaux puissent légaliser leur situation. Il examine le cas des immigrants illégaux provenant d'Europe et du Mexique, et la façon dont les politiques divergeaient par rapport à chaque groupe, en produisant ainsi des conséquences distinctes à court et à long-terme par rapport au statut racial, à la condition face à la loi et à la légitimité sociale de chacun d'eux. L'article soutient que ces trajectoires "racialisées" n'ont pas été entièrement le résultat du racisme existant, mais ont été plutôt engendrées par les distinctions administratives et légales entre les étrangers criminels et ceux qui croisaient la frontière de façon clandestine, lesquelles, de façon sélective, ont produit et ont renversé (?) la condition d'étrangers illégaux (?).

Mots-clés: Immigration - Déportation - Frontière 
Em janeiro de 1930, funcionários do Departamento de Imigração dos Estados Unidos (Bureau of Immigration) testemunharam sobre a Patrulha de Fronteira (Border Patrol), em uma seção fechada do Comitê de Imigração da Câmara dos deputados (House Immigration Committee). Henry Hull, o Comissário Geral de Imigração, explicou que a Patrulha não operava "na linha de fronteira", mas sim até cem milhas "antes dela". A Patrulha de Fronteira, disse ele, era "uma organização de patrulhamento e de perseguição... [os Guardas] operam nas estradas sem mandados de prisão e sempre que eles encontram um estrangeiro eles o param. Se ele está ilegalmente no país, eles o levam para a sede da unidade". 1

George Harris, o Comissário Geral Assistente, acrescentou que o Congresso tinha autorizado a Patrulha da Fronteira a prender estrangeiros sem mandados de prisão, em 1925. É verdade, afirmou Harris, que a lei previa a prisão sem mandado quando um estrangeiro "entra na presença ou no campo de visão [...] do Guarda [de fronteira], mas isso não significa necessariamente que o guarda [de fronteira] tem que ver o estrangeiro no exato momento em que ele atravessa a fronteira para os Estados Unidos. A entrada é uma ofensa continuada e não se completa... até o estrangeiro chegar a seu destino final". ${ }^{2}$

Membros do Comitê de Imigração expressaram sua preocupação de que a Patrulha de Fronteira, que não era uma agência de execução do código penal e não tinha autoridade estatutária para executar mandados de busca, tivesse definido sua jurisdição não somente na fronteira, mas também muito além dela, no interior da nação - no mínimo, cem ou duzentas milhas além da fronteira, mas, teoricamente, todo o interior. Se, como disse Hull, "onde quer que os [guardas] encontram um estrangeiro, eles os param”, como os guardas saberiam a diferença entre um estrangeiro e um cidadão? Aliás, o que

1 Transcrito, depoimento ante a Seção Executiva do Comitê da Câmara dos Deputados sobre Imigração e Naturalização (de agora em diante "House Immigration Commitee"), 15 de janeiro de 1930, arquivo 55688/876-1, entrada 9, Registros do Serviço de Imigração e Naturalização, Grupo de Registro 85, Arquivos Nacionais, Washington (de agora em diante "INS"). ${ }^{2}$ Ibidem. Ato de 27 de fevereiro de 1925 (43 Stat. 1049). A política do Bureau equivalia a uma interpretação ampliada de um julgamento da Corte Federal de 1916, Lew Moy et al. v. Estados Unidos (237 Fed. 50). Nesse caso, a Corte suspendeu a prisão de estrangeiros chineses a 200 milhas ao norte da fronteira com o México, porque, assim, o dito ato de conspiração para contrabandear ainda não teria sido completado. Commissioner General of Immigration to the Secretary of Labor, Annual Report (de agora em diante INS Annual Report), Comissário Geral de Imigração ao Secretário de Trabalho, Relatório Annual_(de agora em diante Relatório Anual do INS), ano fiscal terminando em 30 de junho de 1930, p. 36; "Guarda da Fronteira de Imigração" (audiência preliminar, não revisada), 5 de março de 1928, Audiências ante o

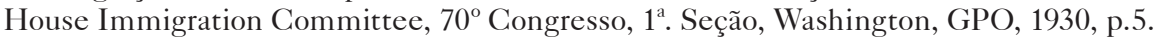


significava o fato de que os guardas da Patrulha de Fronteiras podiam parar, interrogar e revistar, sem um mandado, qualquer um, em qualquer lugar, nos Estados Unidos?

Mas, se o Congresso estava preocupado com o raio de ação da Patrulha de Fronteira, ele próprio tinha quase assegurado uma situação dessas, ao aprovar os Atos de Imigração de 1921 e 1924, que impuseram pela primeira vez limites numéricos à imigração. Porque a entrada ilegal é concomitante com a política de imigração, as leis de quotas estimularam o surgimento de estrangeiros ilegais e criaram esse problema nos espaços internos da nação. Embora a entrada ilegal tivesse sempre resultado em expulsão, na década de 1920, a imigração ilegal atingiu proporções maciças e a deportação ocupou um lugar central na política de imigração. A natureza e as exigências da restrição levantaram uma série de problemas para o estado moderno, que eram simultaneamente administrativos (como se podem impor restrições?), jurídicos (como se pode definir soberania?) e constitucionais (os imigrantes ilegais têm direitos?).

Essas perguntas tinham sido respondidas com relativa facilidade no final do século XIX, quando os imigrantes ilegais se compunham de chineses e outras pessoas marginalizadas (criminosos, loucos, prostitutas etc.) e estipulava-se que os imigrantes podiam ser sumariamente expulsos dos Estados Unidos. Apoiando a exclusão dos chineses, a Suprema Corte americana, nos anos 80 e 90 do século XIX, delegou poder, ao largo da Constituição, ao Congresso para regulamentar a imigração, invocando a soberania nacional, um poder entendido como absoluto. A Corte considerou essa atitude necessária para proteger a nação da invasão estrangeira, quer de exércitos durante tempos de guerra, quer de imigrantes estrangeiros durante tempos de paz. A doutrina do poder total privilegiou a soberania da nação de forma absoluta sobre os direitos dos indivíduos. Assim, a Corte declarou que os estrangeiros não tinham o direito de "permanecerem neste país, exceto por licença, permissão e tolerância do Congresso". Na era da restrição numérica à imigração, o exercício deste poder soberano sobre os imigrantes, especialmente aqueles ilegais, fez com que surgissem questões complexas e perturbadoras. ${ }^{3}$

O presente ensaio examina o advento da imigração ilegal maciça e da política de deportação, sob o Ato de Imigração de 1924, e como essas tendências

\footnotetext{
${ }^{3}$ Chae Chan Ping v. EUA, 130 EUA 581(1889); Nishimura Eiku v. EUA, 142 US 652, 659 (1892); Fong Yue Ting v. EUA, 149 EUA 698, 706, 723 (1893). Ver também Linda S. Bosniak, "Membership, equality, and the difference that alienage makes" ["Sociedade, igualdade, e a diferença que o ser estrangeiro produz”], NYU Law Review, 69 (Dez. 1994): 1047-1149.
} 
alteraram os significados de inclusão e exclusão da nação. Ele sustenta que a restrição numérica criou uma nova classe de pessoas dentro do "corpo da nação" - os estrangeiros ilegais - cuja inclusão na nação era simultaneamente uma realidade social e uma impossibilidade legal. Essa contradição desafiou as noções estabelecidas de soberania e democracia de diversas maneiras. Primeiramente, o aumento no número de entradas ilegais criou uma nova ênfase no controle das fronteiras terrestres contíguas da nação, com uma intensidade que não tinha existido antes. Essa nova articulação da territorialidade do Estado reconstruiu as fronteiras nacionais e o espaço nacional em formas altamente visíveis e problemáticas. Ao mesmo tempo, a noção de controle da fronteira obscureceu o deslocamento inevitável do foco da política para o interior, como sugerido acima.

Em segundo lugar, a aplicação das leis de deportação resultou em um discurso político e legal de oposição, que imaginava imigrantes ilegais merecedores e não merecedores e, concomitantemente, deportações justas e injustas. Essas categorias foram construídas a partir de idéias modernas sobre desejabilidade social, em particular referentes a crime e moralidade sexual, bem como valores que avaliavam a preservação da família. Os críticos argumentavam que a deportação era injusta em casos em que se separavam famílias ou se exigiam outros sofrimentos que eram fora de proporção em relação à ofensa cometida. Como resultado disso, durante a década de 1930, a política de deportação tornou-se objeto de reforma legal que objetivava permitir o discernimento administrativo em casos de deportação. Da mesma forma que a restrição e a deportação "criavam" estrangeiros ilegais, o discernimento administrativo "desfazia" imigrantes ilegais.

Juntas, essas tendências redefiniram a base normativa da desejabilidade social e da inclusão na nação. Esse processo teve uma importante dimensão racial, pois a aplicação e reforma da política de deportação teve efeitos díspares sobre europeus e canadenses, por um lado, e mexicanos, por outro lado. Todavia, tal disparidade não era simplesmente o resultado do racismo existente. Ao invés disso, os processos de redefinição territorial e sanção administrativa informaram maneiras divergentes da racialização dos imigrantes. A tendência era de dissociar os europeus e os canadenses da categoria real ou imaginária de estrangeiro ilegal, o que facilitava sua assimilação nacional e racial como cidadãos brancos americanos. Em contraste, os mexicanos surgiram como estrangeiros ilegais icônicos. O status de ilegal tornou-se constitutivo de uma 
identidade mexicana racializada e da exclusão dos mexicanos da comunidade social e da polity em geral.

\section{Política de deportação e a fabricação dos estrangeiros ilegais}

O imigrante ilegal não pode ser constituído sem deportação - a possibilidade ou ameaça de deportação, se não o fato em si. A possibilidade advém da existência real de um aparato estatal para prender e deportar imigrantes ilegais. A ameaça permanece na "defasagem" temporal e espacial que existe entre o ato de entrada ilegal e a prisão ou deportação (no caso de o imigrante ilegal, de fato, ser pego). ${ }^{4}$

A deportação não foi inventada na década de 1920, mas foi naquela época que ela atingiu a maioridade. De certa forma, as provisões legais para a deportação de imigrantes indesejados existiam na América desde os tempos coloniais, tendo sido o princípio derivado das leis inglesas referentes aos pobres. Uma lei de Massachusetts de 1794, por exemplo, pedia a expulsão dos pobres das cidades e sua repatriação às cidades de onde eles vieram, ou "para qualquer outro Estado, ou qualquer lugar alémmar, onde ele pertença”. A despesa da remoção transatlântica, no entanto, significou que as deportações para a Europa raramente aconteciam, se chegaram a acontecer. As Leis Referentes aos Estrangeiros e Sedição (Alien and Sedition Laws, 1798-1801) previam a exclusão e expulsão de estrangeiros por motivos políticos. Mas os americanos logo rejeitaram o princípio de remoção política durante os tempos de paz e a nação operou sem regulamento federal de imigração durante a maior parte do século XIX. A migração livre era crucial para a colonização e a industrialização da

\footnotetext{
${ }^{4} \mathrm{O}$ registro oficial não deixa de ter seus problemas. Os dados sobre prisões e deportações não representam todas as entradas fora da lei e são ainda tendenciosos em função de decisões políticas de policiar certas áreas ou populações e não outras. Sobre as metodologias usadas ver "Illegal Alien Resident Population" ["População Residente Estrangeira Ilegal”], INS Statistical Yearbook (1998) [Livro do Ano de Estatística do INS (1998)]. Ver também Barry Edmonston, Jeffrey Passel e Frank Bean, Undocumented migration to the US: IRCA and the experience of the 1980s [Migração não-documentada para os EUA: IRCA e a experiência dos anos 80], Santa Monica, Ca., Rand Corporation, 1990, p. 16-18, 27. Agradeço a Neil Gotanda por sugerir que o conceito racial de "passing" pode ser aplicado a imigrantes ilegais.
} 
América, mesmo se os trabalhadores migrantes eles mesmos não fossem sempre livres. ${ }^{5}$

O Congresso aprovou as primeiras leis federais restritivas quanto à entrada, em 1875, quando baniu pessoas condenadas por "crimes envolvendo depravação moral" e prostitutas (uma provisão que objetivava impedir que as mulheres chinesas entrassem no país). Durante os anos 80 do século XIX, o número de classes passíveis de expulsão cresceu, incluindo os retardados mentais, os trabalhadores contratados, as pessoas com "doenças perigosas, asquerosas e contagiosas", os pobres, os polígamos e os "imbecis" e "insanos", bem como os trabalhadores chineses. A ladainha de classes passíveis de expulsão enunciou uma preocupação em relação à admissão de pessoas que poderiam ser um "peso público" (real ou imaginado), bem como as crenças do final do século XIX, derivadas do Darwinismo Social e da antropologia criminal, que o corpo da nação tinha de ser protegido das contaminações da decadência social. ${ }^{6}$

Mesmo assim, as fronteiras da nação eram permeáveis, com controle pouco rigoroso e, em grande parte, desprotegidas. A inspeção na chegada procurava identificar as pessoas deportáveis e negar-lhes entrada, mas pouco podia ser feito se essas evitassem a identificação e entrassem no país. A descoberta

\footnotetext{
${ }^{5}$ Gerald L. Neuman, Strangers to the Constitution: immigrants, borders, and fundamental law [Estranhos para a Constituição: imigrantes, fronteiras, e lei fundamental], Princeton, Princeton University Press, 1996, p. 19-43; Kunal Parker, "From Poor Law to Immigration Law: changing visions of territorial community in Antebellum Massachusetts" ["Da Lei dos Pobres para a Lei de Imigração: Mudando visões de comunidade territorial em Antebellum Massachusetts"], Historical Geography, 28, 2000, p. 61-85. Sobre a migração e o desenvolvimento econômico no século XIX ver David Montgomery, The fall of the House of Labor [A queda da Casa de Trabalho], New York, Cambridge University Press, 1987, p. 70-74; John Bodnar, The transplanted [Os transplantados], Bloomington, Indiana University Press, 1985, p. xviii-xix; Aristide Zolberg, "Global movements, global walls: responses to migration, 1885-1925" ["Movimentos globais, muros globais: respostas para a migração, 1885-1925”], em Global history and migrations [História global e migrações], org. Wang Gungwu, Boulder, Col., Westview, 1997, p. 279. Sobre a transição do regulamento estadual para o federal de imigração ver Mary Sarah Bilder, "The struggle over immigration: indentured servants, slaves, and articles of commerce" ["A luta pela imigração: trabalhadores contratados, escravos e os artigos do comércio”], Missouri Law Review, 61, 1996, p. 744-824.

${ }^{6}$ Edward Hutchinson, Legislative History of American Immigration Law, 1798-1965 [História Legislativa da Lei de Imigração Americana, 1798-1965], Philadelphia, University of Pennsylvania Press, 1981, p. 163-168; 22 Stat 58 (Primeira Lei de Exclusão Chinesa, 1882); 22 Stat 214 (Ato de Imigração de 1882); 23 State 332 (Alien Contract Labor Law [Lei Trabalhista de Contratos de Estrangeiros], 1885. Sobre a antropologia do crime, coolieism anti-chinês e anti-modernismo do final do século XIX, ver Colleen Lye, Model modernity: the making of asiatic racial form, 1882-1943 [Modernidade modelo: o fazer da forma racial asiática], Tese de Doutorado, Columbia University, 1999.
} 
subseqüente era freqüentemente o resultado de essas pessoas serem hospitalizadas ou presas; mesmo assim, não existia uma lei federal exigindo a remoção dos estrangeiros que eram um "peso público" ao país. Somente em 1891, o Congresso autorizou a deportação de estrangeiros que, antes de completarem um ano de sua chegada, se tornassem alvo de acusações públicas por causas anteriores à entrada. Tal deportação seria por conta da companhia a vapor que originalmente os transportara. O Congresso não estabeleceu qualquer outro mecanismo de exclusão e não alocou fundos para a deportação. ${ }^{7}$

Aos poucos, porém, o Congresso ampliou o estatuto de limitação à deportação. O Ato de Imigração de 1917 adicionou seis categorias passíveis de deportação e sanções mais severas, ampliou para cinco anos o período durante o qual a deportação era possível, retirou todos os limites de tempo para estrangeiros de certas classes e, pela primeira vez, alocou fundos para a execução das determinações do Ato. Essa nova e severa lei foi usada contra imigrantes anarquistas e comunistas, em uma onda de vingança do pós-guerra contra o radicalismo e a militância trabalhista, culminando com as Incursões Palmer (Palmer Raids), no inverno de 1919-1920, nas quais as autoridades prenderam 10 mil supostos anarquistas e terminaram por deportar uns 500 deles. $^{8}$

Não obstante esse Medo Vermelho, poucas pessoas foram de fato expulsas ou deportadas antes da década de 1920. Entre 1892 e 1907, o Serviço de Imigração deportou somente algumas centenas de estrangeiros por ano e, entre 1908 e 1920, uma média de dois a três mil por ano - a maioria dos estrangeiros retirados de asilos, hospitais e prisões. A deportação parece ainda menos significativa quando se considera que cerca de um milhão de pessoas por ano entrou no país na década anterior à Primeira Guerra Mundial. O Congresso e o Serviço de Imigração conceberam e executaram a deportação como um acessório ao processo de exclusão, uma correção à admissão não-apropriada de estrangeiros passíveis de expulsão. ${ }^{9}$ Talvez o mais importante seja que

\footnotetext{
${ }^{7}$ Hutchinson, Legislative History [História Legislativa], p. 447.

${ }^{8}$ O Congresso estendeu a limitação estatutária para deportação para dois anos, a partir da época da entrada em 1903 (32 Stat. 1213), e para três anos, em 1907 (34 Stat. 898). Sobre Palmer Raids, ver William Preson Jr. Aliens and dissenters: federal suppression of radicals, 19031933 [Estrangeiros e dissidentes: supressão federal dos radicais, 1903-1933], Cambridge, Mass., Harvard University Press, 1963.

${ }^{9}$ Historical statistics of the US from colonial times to 1970 [Estatistica historica dos EUA dos tempos coloniais até 1970], Washington, GPO, 1975, p. 105, 113; INS Annual Report [Relatório Annual do INS], 1921, p.14-15; William Van Vleck, Administrative control of aliens [Controle administrativo dos estrangeiros], New York, Commonwealth Fund [Fundo da Commonwealth], 1932, p. 20. Ver também Jane Perry Clark, Deportation of aliens from the U.S. to Europe [Deportação de estrangeiros dos EUA para a Europa], New York, Columbia University Press, 1931, p. 275.
} 
a mera entrada sem inspeção era razão insuficiente para a deportação. O estatuto de limite à deportação era consistente com a filosofia geral do melting pot e da assimilação cultural: parecia injusto expulsar imigrantes depois que eles tinham se estabelecido no país e tinham começado a se assimilar.

Um novo regime de política de imigração começou na década de 1920: o regime de restrição numérica, que encerrou a política histórica de imigração aberta da Europa. Desenvolvimentos políticos e econômicos, tanto nacionais como globais, influenciaram essa mudança. Um sentimento anti-estrangeiro nos Estados Unidos tinha aumentado desde os meados dos anos 80 do século XIX, em sua maior parte em resposta aos problemas sociais que pareciam associados com a migração em massa do sul e leste da Europa: favelas urbanas, doença, pobreza, conflito de classes. De forma mais imediata, a Primeira Guerra Mundial tinha feito surgir um nacionalismo e um sentimento anti-estrangeiro agudos. A restrição à imigração foi um componente central da política de nacionalismo dos tempos de guerra e da reação pós-guerra. Também houve influências estruturais. Em 1920, o sistema de produção industrial em massa tinha amadurecido a tal ponto que a produção aumentada derivava da evolução tecnológica, e não do aumento na chegada de mão-de-obra não-especializada. De forma mais geral, a restrição à imigração fazia parte de uma nova idade global. A Primeira Guerra Mundial marcou a consolidação do sistema internacional de nação-estado, baseado na soberania "westfaliana”: fronteiras mais controladas, cidadania em estados-nações e controles de passaportes. ${ }^{10}$

Em 1921, o Congresso restringiu a imigração para os Estados Unidos a 350 mil por ano. O Ato de 1924 restringiu ainda mais a imigração, limitando novas entradas a 150 mil por ano: menos que 15 por cento da média anual dos anos antes da Guerra. ${ }^{11}$ Foram determinadas quotas para os países em propor-

\footnotetext{
${ }^{10}$ John Higham, Strangers in the Land: patterns of nativism in the US 1850-1924 [Estranhos na Terra: padrões de nativismo nos EUA 1850-1924], New Brunswick, NJ, Rutgers University Press, 1985, 1955, p. 204-07, 301; Montgomery, Fall of the House of Labor [Queda da Casa de Trabalho], p. 457-58; Saskia Sassen, Guests and Aliens [Convidados e Estrangeiros], New York, New Press, 1999, p. 83-84; John Torpey, The invention of the passport [A invenção do passaporte], New York, Cambridge University Press, 2000, p. 111-121; Aristide Zolberg, "The great wall against China" ["A grande parede contra a China"], in: Jan Lucassen e Leo Lucassen (org.), Migration, Migration History, History: old paradigms and new perspectives [Migração, História da Migração, História: velhos paradigmas e novas perspectivas], Berna e New York, Peter Lang, 1997.

${ }^{11}$ Ato de 19 de maio de 1921 (41 Stat. 5); Ato de 26 de maio de 1924 (43 Stat, 153); Historical statistics [Estatística histórica], p. 105. Nem toda a imigração estava sujeita à quota numérica. Membros da família imediata de cidadãos americanos podiam imigrar fora do limite de quotas, como "imigrantes sem quota". Nativos dos países do Hemisfério Ocidental não estavam sujeitos a quotas. Ao mesmo tempo, todos os asiáticos estavam excluídos como "pessoas inelegíveis para a cidadania”. As quotas, então, eram direcionadas principalmente aos países europeus.
} 
ção aos números que os americanos identificavam como o "país de origem" de seus antepassados. Abordei a questão das dimensões raciais do sistema nacional de quotas em outra publicação. ${ }^{12}$ Relevante para essa discussão é o outro aspecto central da lei - a restrição a números e seus concomitantes -, a imigração ilegal e a deportação.

A mudança para as leis de quotas foi marcante, tanto quanto ao volume como quanto à natureza da entrada ilegal, bem como em relação à filosofia e à prática da deportação. Em geral, é claro, os legisladores criam leis para incluir sanções contra suas violações. Todavia, no Ato de 1924, o Congresso evidenciou uma abordagem totalmente distinta em relação à deportação, indo além do que tinha feito anteriormente. A nova lei eliminava o estatuto de limite quanto à deportação para quase todas as formas de entrada ilegal e previa a deportação em qualquer ocasião para qualquer pessoa que entrasse depois de

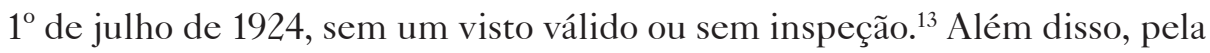
primeira vez, o Congresso legislou um mecanismo sério de repressão contra a entrada ilegal, criando a Patrulha de Fronteira terrestre. ${ }^{14}$

Depois de 1925, houve um aumento dramático no número de deportações. Um contemporâneo observou que o "uso extensivo de poder para expulsar" começou em 1925 e que a deportação tornou-se rapidamente "uma das principais atividades do Serviço de Imigração em alguns distritos". ${ }^{15}$ Para tornar a expulsão mais eficiente, em 1927, o Serviço de Imigração permitiu que os estrangeiros ilegais sem registros criminais partissem voluntariamente, assim economizando tempo e despesa de instituir procedimentos formais de deportação. O número de estrangeiros expulsos do país aumentou de 2.762 em 1920, para 9.495 em 1925 e 38.795 em 1930. ${ }^{16}$ "Estrangeiros sem vistos apro-

\footnotetext{
${ }^{12}$ Mae M. Ngai, "The architecture of race in American Immigration Law: a re-examination of the Immigration Act of 1924" ["A arquitetura da raça na Lei de Imigração Americana: um reexame do Ato de Imigração de 1924"], Journal of American History [Revista de História Americana], 86, June, 1999, p. 67-92. Ver também Robert A. Divine, American Immigration Policy [Politica de Imigração Americana], New Haven, Yale University Press, 1957; John Higham, Strangers in the Land [Estranhos na Terra]; Desmond King, Making americans [Fazendo americanos], Cambridge, Mass., Harvard University Press, 2000.

${ }^{13}$ Ato de maio de 1924, Sec. 14. Aqueles que entraram antes de 1924 continuaram a ser sujeitos à deportação de acordo com os termos do Ato de Imigração de 1917.

${ }^{14}$ Ato de 27 de fevereiro de 1925 (43 Stat. 1049); Ato de 4 de março de 1929 (45 Stat. 1551).

${ }^{15}$ Van Vleck, Administrative control [Controle Administrativo], p. 21; Relatório Annual do INS, 1925, p. 9.

${ }^{16}$ Historical statistics [Estatísticas históricas], p. 114. Os números incluem a deportação sob mandato formal e partidas voluntárias.
} 
priados" rapidamente se tornaram a maior classe de deportados, representando mais da metade do número total de deportações formais e a maioria absoluta das partidas voluntárias nos últimos anos da década de $1920 .{ }^{17}$

Essa mudança nas principais categorias de deportação causou novas formas de pensar a imigração ilegal. Em primeiro lugar, o status de legal/ilegal se tornou, efetivamente, uma construção abstrata, tendo menos a ver com a experiência do que com números e papel. O status legal de uma pessoa agora se baseava em estar no lugar correto na fila - se um país tinha uma quota "N" de imigrantes, o imigrante " $\mathrm{N}$ " era legal, mas o imigrante "N+1" era ilegal18 - e ter a documentação correta, o premiado "visto apropriado". Essas não eram categorias absolutas, é lógico, na medida em que as categorias de preferência privilegiavam certas relações familiares e índices qualitativos para expulsão permaneciam válidos. No entanto, os aspectos qualitativos da admissão se tornaram menos visíveis por terem sido absorvidos pelo processo de pedido de visto, que, depois de 1924, passou a acontecer nos escritórios consulares dos Estados Unidos no exterior. Além de supervisionar a distribuição de quantidades de quotas, os cônsules americanos determinavam a desejabilidade de migrantes potenciais, com quota e sem quota, de acordo com a apresentação de um "dossiê", questionário e entrevista, bem como certidão médica. ${ }^{19}$ Em 1924, o Serviço de Imigração encerrou a inspeção médica por fila na Ellis Island porque as exclusões por motivos médicos passaram a ser decididas no exterior. Assim, ao chegarem, os vistos dos imigrantes eram inspecionados; não seus corpos. O sistema, então, mudou para um registro diferente, mais abstrato, que privilegiava o status formal acima de qualquer outra coisa. É esse sistema que resultou no que hoje chamamos "imigrante não-documentado".

O estrangeiro ilegal, que é definido abstratamente, embora também inegavelmente dotado de um corpo, é, dessa forma, um espectro, um corpo do qual foi retirada a individualidade pessoal, cuja presença em si é perturbadora, injuriosa. Além disso, esse corpo despojado de personalidade não tem direitos. Não é coincidência que o regime de restrição de imigração tenha surgido com a Primeira Guerra Mundial. A guerra, simultaneamente destruindo a estabilidade geopolítica da Europa e solidificando o sistema de nação-estado, também

\footnotetext{
${ }^{17}$ Relatório Anual do INS, 1931, p. 255-256.

${ }^{18}$ Agradeço a Kunal Parker por sugerir essa formulação ilustrativa.

${ }^{19}$ Ato de 24 de maio de 1924, Sec 7 (b), (d).
} 
criou milhões de refugiados e pessoas apátridas, bem como desnacionalizou e desnaturalizou pessoas durante o período pós-guerra. ${ }^{20}$ Lembrando Hannah Arendt, o filósofo Giorgio Agamben nos diz: "No sistema de nação-estado, os assim chamados direitos sagrados e inalienáveis do homem se mostram como vazados de qualquer proteção e realidade no momento em que eles não mais têm a forma de direitos pertencentes aos cidadãos de um Estado". Certamente, o estrangeiro ilegal aparece no mesmo momento histórico e na mesma terra-de-ninguém jurídica que foi criada quando a guerra afrouxou as ligações entre nascimento e nação, ser humano e cidadão. ${ }^{21}$

Em segundo lugar, a simples idéia de que pessoas sem status legal viviam na nação provocou imagens de grande perigo. Em 1925, o Serviço de Imigração relatou, com algum alarme, que 1.4 milhão de imigrantes 20 por cento daqueles que entraram no país antes de 1921 - poderiam já estar vivendo ilegalmente nos Estados Unidos. O Serviço admitia que os imigrantes tinham entrado legalmente no país, mas porque ele não tinha registro de suas entradas, ele os considerava ilegais. ${ }^{22}$

Em 1927, o Bureau de Imigração relatou que o "contrabando de estrangeiros ilegais" era "uma indústria lucrativa que só era ultrapassada pelo contrabando de bebidas alcoólicas". E enfatizou: "O estrangeiro contrabandeado é indubitavelmente o menos desejável. O que mais possa ser dito acerca dele: quer ele seja enfermo ou não, quer ele tenha opiniões contrárias a nossas instituições, ele é, na melhor das hipóteses, um violador da lei desde o começo" (ênfase acrescentada). ${ }^{23}$ Essa opinião de que o imigrante sem documentação era o estrangeiro menos desejável de todos revela uma nova concepção de

${ }^{20}$ Giorgio Agamben, Homo sacer: sovereign power and bare life [Homo sacer: poder soberano e a vida nua], Stanford, Stanford University Press, 1998, p. 130-31. Ver também Hannah Arendt, The origins of totalitarianism [As origens do totalitarismo], New York, Harcourt Brace, 1979, 1951, p. 267-302. De acordo com Agamben, os refugiados e as pessoas apátridas criados pela Primeira Guerra Mundial incluíram 1.5 milhão de Bielorussos, 700.000 armênios, 1 milhão de gregos, 500.000 búlgaros, e centenas de milhares de alemães, húngaros e romenos. França (1915) e Bélgica (1922), Itália (1926) e Áustria (1933) desnacionalizaram as pessoas de "origem inimiga" e outras consideradas não-merecedoras de cidadania por razões de nascimento, culminando, é claro, com as leis de cidadania de Nuremberg e os campos de concentração nazistas. Agamben observa que "Uma das poucas regras que os nazistas consistentemente seguiam durante o curso da 'Solução Final' foi a de que os judeus somente podiam ser enviados aos campos de extermínio quando tivessem sido desnacionalizados (subtraída até mesmo a cidadania restante deixada depois das leis de Nuremberg)".

${ }^{21}$ Ibidem, p. 126.

22 INS Annual Report [Relatório Anual do INS], 1925, p. 12-13.

${ }^{23}$ Relatório Annual do INS, 1927, p. 15-16. 
nação, que coloca o princípio de soberania nacional como prioritário. Ela tornou a territorialidade do Estado - não as necessidades de mão-de-obra, não a reunião familiar, não a fuga da perseguição, não a assimilação - como a força motriz da política de imigração.

No entanto, a territorialidade era altamente instável, precisamente porque a restrição tinha criado imigrantes ilegais dentro da própria nação. Esse não era um fenômeno completamente novo, mas conseqüências importantes resultaram da natureza e escala distintas da imigração ilegal no final da década de 1920. Os imigrantes ilegais se compunham agora de todas as nacionalidades e grupos étnicos. Eles eram numerosos, talvez até incontáveis, e estavam espalhados por toda a nação, particularmente pelas grandes cidades; eles podiam ser o(a) esposo(a) de qualquer um, vizinho ou companheiro de trabalho.

O problema de diferenciar imigrantes ilegais de cidadãos e imigrantes legais evidenciou o perigo que os defensores de restrições à imigração tinham imaginado - para eles, os estrangeiros ilegais eram inimigos invisíveis no meio da América. Mas as soluções por eles propostas, como o registro obrigatório de estrangeiros e as deportações em massa, eram problemáticos exatamente porque os imigrantes não documentados eram tão parecidos com outros americanos. O problema de diferenciação revelou uma descontinuidade entre a imigração ilegal como um problema geral abstrato, um discurso de "pânico" usado às vezes com grande efeito político, e imigrantes ilegais, que eram pessoas reais conhecidas na comunidade, pessoas que não cometiam faltas substantivas.

\section{A fronteira e a patrulha da fronteira}

Antes da década de 1920, o Serviço de Imigração prestava pouca atenção às fronteiras da nação porque a maioria absoluta dos imigrantes que entravam nos Estados Unidos o fazia pela Ellis Island e outros portos de mar. O fluxo de imigrantes para o país tinha sido não-somente bem recebido, mas tinha sido concentrado em pontos fixos que tornavam as fronteiras da terra invisíveis. Um diretor de imigração descreveu a situação como o "equivalente a um círculo com portas trancadas sem quaisquer paredes entre elas". ${ }^{24}$ Uma pequena força-tarefa do Serviço de Alfândega e a Divisão Chinesa do Serviço

${ }^{24}$ IF Wixon, "Mission of the Border Patrol" ["Missão da Guarda de Fronteira"], Aula n. 7, 19 de março de 1934, Washington, 1934, p. 2. 
de Imigração patrulhavam conjuntamente as fronteiras canadense e mexicana contra a entrada ilegal de chineses. O inspetor da patrulha chinesa, designado para realizar patrulha a cavalo ou inspecionar carros de carga, ocupava o posto mais solitário e mais baixo na hierarquia do Serviço. ${ }^{25}$

Inspetores de imigração ignoravam os mexicanos que entravam no sudoeste dos Estados Unidos durante as duas primeiras décadas do século XX para trabalharem na construção de estradas de ferro, na mineração e na agricultura. O Departamento de Imigração não considerava a imigração mexicana como parte importante de sua jurisdição, mas antes como algo que era "regulado pelas exigências do mercado de trabalho nos estados fronteiriços [do sudoeste]". ${ }^{26}$ Antes da Primeira Guerra Mundial, a fronteira Estados Unidos-Canadá também era bastante permeável e com controle pouco rigoroso. Durante todo o século XIX, os canadenses circulavam livremente pelos Estados Unidos; no entanto, os canadenses não foram uma fonte maior de trabalho não-especializado para a indústria americana. ${ }^{27}$

Se tanto a fronteira mexicana quanto a canadense eram porosas e sem controle estrito até a Primeira Guerra Mundial, a passagem de lei de quotas em 1921 e 1924 colocou as fronteiras de terras contínuas da nação em grande evidência para as autoridades da imigração. Embora a maioria dos imigrantes da Europa continuasse a chegar pelos portos marítimos, os contemporâneos imaginavam que os estrangeiros ilegais invadissem pelas fronteiras terrestres. Um escritor, acreditando que "a onda de imigração agora chega às fronteiras terrestres - não às costas marítimas - dos Estados Unidos," indagou: "essas fronteiras extensas podem algum dia ser patrulhadas adequadamente?" 28

${ }^{25}$ A Divisão Chinesa foi também chamada a Divisão de Fora, porque operava separadamente do Serviço de Imigração principal. Em geral, a Divisão de Fora tinha pouco pessoal e "não era talentosa". Clifford Perkins, Border Patrol: with the US Immigration Service on the mexican boundary 1910-1954 [Guarda de Fronteira: com o Serviço de Imigração dos EUA na fronteira mexicana 1910-1954], El Paso, Texas Western Press, 1978, p. 9, 75.

${ }^{26}$ George Sánchez, Becoming mexican american [Tornando-se mexicano americano], New York, Oxford University Press, 1993, p. 52-53; INS Annual Report [Relatório Anual do INS], 1919, p. 24-25, 61 .

27 Depoimento de TG Gallagher, Continental Sugar Co, Toledo, in: "Immigration from countries of Western Hemisphere" ["Imigração de países do Hemisfério Ocidental"], Hearings before House Immigration Committee [Audiências ante o House Immigration Committee], 70 Congresso, 1a. Seção, Feb. 21-Apr. 5, 1928, p. 555-557; entrevista de história oral com Rudolfo M. Andres por Helen Hatcher, 27 de junho de 1981, arquivo BA/ NC81-Fil-004-HMH-1, Demonstration Project for asian americans [Projeto de Demonstração para americanos de origem asiática], Seattle.

${ }^{28}$ Survey, 19 de janeiro de 1929, p. 480. 
$\mathrm{Na}$ verdade, os imigrantes ilegais europeus entravam nos Estados Unidos por ambas as fronteiras. Uma investigação do Bureau Federal de Investigação (FBI), em 1925, relatou que "milhares" de imigrantes, "a maioria deles recémchegados da Europa”, estavam "vindo [para o Canadá] tão rápido quanto eles pudessem conseguir dinheiro para pagar aos contrabandistas". Mas a rota mais utilizada para a imigração européia ilegal era pelo México. ${ }^{29}$

Pelo final da década de 1920, a entrada clandestina nos Estados Unidos de europeus diminuiu. A ameaça de prisão e deportação era um impedimento, mas também métodos alternativos legais existiam para driblar as leis de quotas. Os europeus podiam ir para o Canadá e serem admitidos nos Estados Unidos legalmente depois que residissem no Canadá por cinco anos. A evidência sugere que essa era uma estratégia popular: a proporção de entradas legais no Canadá de pessoas não-nascidas no Canadá aumentou de 20 por cento em 1925 para mais de 50 por cento nos primeiros anos da década de 1930. ${ }^{30}$ $\mathrm{E}$, à medida que os imigrantes europeus nos Estados Unidos se tornavam cidadãos naturalizados, eles podiam trazer seus parentes legalmente como imigrantes fora das quotas oficiais. Em 1927, mais de 60 por cento dos imigrantes fora da quota oficial admitidos nos Estados Unidos eram da Itália, sendo os grupos maiores depois desse da Polônia, Checo-Eslováquia e Grécia. ${ }^{31}$

Isso não quer dizer que a imigração ilegal de europeus e canadenses tivesse parado. O Serviço de Imigração continuou a deportar estrangeiros ilegais para a Europa e para o Canadá - as deportações permaneceram bem constantes na faixa de 6.000 a 8.000 por ano, durante os primeiros anos da década de 1930. Mas o número de pessoas deportadas por entrada clandestina diminuiu, enquanto que o número de deportados por ficarem além do prazo de seus vistos temporários aumentou. ${ }^{32}$

O trabalho do Serviço de Imigração na fronteira canadense contrastava com o que o Comissário Geral descrevia como "o auge" de seu trabalho ao longo da fronteira Estados Unidos-México. ${ }^{33}$ Durante os últimos anos da década de 1920, o número de imigrantes mexicanos ilegais deportados pela

\footnotetext{
${ }^{29}$ Walter Elcarr para o Comissário Geral, 11 de janeiro de 1924; WJ Egan para John H. Clark, 25 de março de 1924; John Clark para o Comissário Geral, 27 de março de 1924; arquivo 53990/160A, caixa 792, accesso 60A600, INS; WF Blackman, "Smuggling of aliens across the canadian border," ["Contrabando de estrangeiros pela fronteira canadense"], 21 de janeiro de 1925, arquivo 53990/160C, ibid.; INS Annual Report [Relatório Annual do INS], 1923, p. 16.

${ }^{30}$ Relatório Annual do INS, 1925, p. 9, 18; Relatório Anual do INS, 1929, p. 7; Relatório Anual do INS, 1930, p. 13; Relatório Anual do INS, 1931, p. 24; Relatório Anual do INS, 1932, p. 17.

${ }^{31}$ Relatório Anual do INS, 1927, p. 12.

32 Relatório Anual do INS, 1924-1932.

${ }^{33}$ Relatório Anual do INS, 1925, p. 19.
} 
fronteira sul disparou de 1.751 expulsões, em 1925, para mais de 15.000, em 1929. ${ }^{34}$ As deportações por entradas sem um visto adequado representavam a maior parte do aumento. Embora os mexicanos não tivessem restrições de quotas, eles enfrentavam mesmo assim um sem-número de exigências, como a taxa por cabeça e a taxa do visto, que faziam com que muitos evitassem a admissão e a inspeção formais.

Os mexicanos vindo para os Estados Unidos encontravam um novo tipo de fronteira. Apesar dos procedimentos de imigração não-rígidos antes da Primeira Guerra Mundial, a fronteira Estados Unidos-México tinha tido uma longa história de contestação. Nascida como resultado da guerra e da anexação, ela foi contestada literalmente a partir de sua primeira concepção, pelos agrimensores mexicanos e americanos encarregados de determinar a fronteira depois da guerra mexicano-americana. Consolidar a soberania americana no território conquistado era um processo demorado, pois escaramuças armadas e rebeliões ao longo da fronteira acompanhavam a apropriação de terras e a imposição das instituições políticas americanas. Somente após uma década de instabilidade ocasionada pela Revolução Mexicana e pela Primeira Guerra Mundial, é que a fronteira como um marco político tornouse basicamente fixa. ${ }^{35}$

Durante a década de 1920, a política de imigração rearticulou a fronteira Estados Unidos-México como uma fronteira cultural e racial, como uma geradora de imigração ilegal. Funcionários federais conscientemente entenderam sua tarefa como a de criar uma barreira onde, em um sentido prático, não tinha havido antes. O Serviço de Imigração instituiu novas políticas - novos procedimentos de inspeção e a formação da Patrulha de Fronteira - que acentuaram a diferença entre os dois países. Como o historiador George Sánchez descreveu, cruzar a fronteira tornou-se "um acontecimento importante, grave, uma quebra com o passado... um evento doloroso e abrupto permeado por uma atmosfera de racismo e controle - um evento que claramente diferenciava uma sociedade da outra". ${ }^{36}$

\footnotetext{
${ }^{34}$ Depois de 1927, as expulsões incluem tanto deportações formais sob mandado, quanto partidas voluntárias. Relatório Anual do INS, 1928-1932; Secretário de Trabalho, Relatório Anual, 1933-1938.

${ }^{35}$ Leon Metz, Border: the US-Mexico line [Fronteira: a linha EUA-México], E1 Paso, Tex., Mangan Books, 1989, p. 20-40; Oscar Martínez, Troublesome border [Fronteira problemática], Tucson, University of Arizona Press, 1988, p. 17-21, 87.

36 Discurso de John Farr Simmons, Chefe do Escritório de Vistos, Departamento de Estado, na Conferência sobre Imigração, Williamstown, Mass., 1930, p. 7-9, arquivo Sen71A-F11, caixa 93, Registros do Senado dos EUA, Grupo de Registros 46, Arquivos Nacionais (Washington); George Sánchez, Becoming mexican american, [Tornando-se Mexicano-Americano], p. 60-61.
} 
A inspeção na fronteira mexicana envolvia um procedimento degradante de banho, despiolhização, inspeção médica em fila e interrogatório. Os banhos eram novos e singulares para os imigrantes mexicanos, exigindo que eles fossem inspecionados sem roupa, terem seus cabelos cortados e terem suas roupas e bagagem desinfestados. A inspeção médica em fila, que tinha como modelo a prática usada anteriormente na Ellis Island, exigia que os imigrantes caminhassem em fila única na frente de um médico. ${ }^{37}$ Esses procedimentos eram particularmente humilhantes, mesmo desnecessários, pelo fato de que o Ato de Imigração de 1924 exigia dos possíveis imigrantes que eles apresentassem um atestado médico ao cônsul dos Estados Unidos, quando solicitassem um visto, antes de sua viagem para os Estados Unidos. A inspeção médica em fila na Ellis Island acabou em 1924, e em El Paso o Serviço de Imigração isentou todos os europeus e mexicanos que chegassem de trem de primeira classe da necessidade de inspeção médica em fila. Os preconceitos raciais sobre os trabalhadores mexicanos, não a lei, determinavam os procedimentos adotados na fronteira com o México.

Mais do que qualquer outro fato, a formação da Patrulha de Fronteira salientou a existência da fronteira. No distrito da fronteira com o México, o Serviço de Imigração primeiramente recrutou funcionários da guarda, a partir dos registros de funcionários do serviço civil de trem postal, mas isso mostrou-se um erro, já que eles geralmente não eram treinados e o serviço rapidamente esgotou os registros. ${ }^{38}$ Com o benefício da suspensão temporária das exigências do serviço público, o Serviço de Imigração contratou antigos cowboys, trabalhadores qualificados, e pequenos proprietários de ranchos como seus primeiros guardas. Quase todos eram jovens, muitos tinham experiência militar e não poucos eram associados à Ku Klux Klan. ${ }^{39}$

${ }^{37}$ Irving McNeil para JW Tappan, US Public Health Service [Serviço de Saúde Pública dos EUA], 22 de dezembro de 1923; Inspetor encarregado do Inspetor Supervisor, El Paso, 13 de dezembro de 1923, arquivo 52903/29, entrada 9, INS. Ver também "Immigration Border Patrol" ["Guarda de Fronteira de Imigração"], p. 31-32. Imigrantes chineses desembarcando em Angel Island eram sujeitos a uma inspeção médica rigorosa e a interrogação prolongada, mas não a banhos em massa e despiolização. Sobre os procedimentos de inspeção dos chineses, ver Erika Lee, At America's gates: chinese immigration during the exclusion era [Nos portões da América: imigração chinesa na era da exclusão], tese de Ph.D. (Doutorado), Univ. da Califórnia, Berkeley, 1999.

${ }^{38}$ Relatório Anual do INS, 1925, p. 15.

${ }^{39}$ Ibidem; Sánchez, Becoming mexican american [Tornando-se Mexicano Americano], p. 59; David Blackwell para Comissário Regional do Sudoeste, "Border Patrol 50 $0^{\text {th }}$ Anniversary," ["50 Aniversário da Guarda de Fronteira"], 19 de janeiro de 1954, in: Arquivo de História Oral de Edwin Reeves, op. cit. 
Um exame para o serviço público foi logo instituído, que incluía matemática, escrever um ensaio em inglês e demonstrar conhecimento de espanhol "como falado ao longo da fronteira com o México". Durante os últimos anos da década de 1920, a evasão se manteve numa média de 25 por cento nos primeiros seis meses. A falta de profissionalismo assolava a tropa. No distrito de El Paso, beber no emprego, ler ou se reunir com os amigos durante o serviço, dirigir de forma descuidada, espalhar falsos boatos e aceitar suborno dos estrangeiros se tornaram problemas comuns. ${ }^{40}$

Mais importante ainda, o trabalho da Patrulha de Fronteira tomou um caráter de caça e prisão criminais, embora oficialmente estivesse encarregado de vigiar, zelar pelas leis civis e penais e não fosse treinada como agência de repressão ao crime. À medida que os funcionários da Patrulha de Fronteira perseguiam fanaticamente os estrangeiros ilegais, os contrabandistas e os criminosos, o Serviço de Imigração recebia reclamações de americanos brancos que eram interrogados por patrulheiros descorteses ou presos sem mandado. ${ }^{41}$ Como resposta, o Serviço de Imigração treinou guardas para agirem com civilidade, cortesia, e formalidade quando lidassem com cidadãos anglo-saxões, proprietários de ranchos, imigrantes chegando da Europa, e "turistas de alta classe" do Canadá. ${ }^{42}$ Mas as práticas quase ou inteiramente ilegais associadas com o patrulhamento dos rancheiros e com os Texas Rangers se adequavam às necessidades da Patrulha de Fronteira no sudoeste, especialmente quando

${ }^{40}$ David Blackwell para o Comissário Regional do Sudoeste, "Border Patrol 50 ${ }^{\text {th }}$ Anniversary" ["50 Aniversário da Guarda de Fronteira"], Relatório Annual do INS, 1930, p. 37. Circulares Distritais de El Paso por GC Wilmoth, sobre a ida ao México para consumo de álcool, durante e fora do horário de trabalho, número de série 2274, 2 de setembro de 1924, republicado em 16 de fevereiro de 1928; sobre dirigir descuidada e perigosamente e sobre falha em fazer manutenção dos veículos, número de série 4073, 3 de abril de 1929; sobre ler ou "divertir amigos relacionando histórias ou piadas" durante o trabalho, número de série 4136, 21 de novembro de 1929; sobre ocupar-se em "conversa sem utilidade e prejudicial com pessoas de fora", número de série 4133, 19 de novembro de 1929; sobre recebimento de suborno de estrangeiros, número de série $4127,1^{\circ}$ de outubro de 1929, arquivo 55494/25-A, caixa 3 , accesso 58A734, INS. David Blackwell para Comissário Regional do Sudoeste, "Border Patrol 50 ${ }^{\text {th }}$ Anniversary" [" $50^{\circ}$ Aniversário da Guarda de Fronteira”], INS Annual Report [Relatório Anual do INS], 1930, p. 37.

${ }^{41}$ Bisbee Review (Arizona), Feb. 1, 1927; GC Wilmoth para Inspetores da Guarda Principal, 7 de junho de 1929, arquivo 55494/25-A, caixa 3, accesso 58A734, INS; DW MacCormack, "The Spirit of the Service" ["O Espírito do Serviço"] no Depto. de Trabalho dos EUA, Bureau de Imigração, Problems of the Immigration Service: Papers presented at a Conference of Commissioners and District Directors of Immigration [Problemas do Serviço de Imigração: Comunicaşões apresentadas na Conferência dos Comissários e Diretores do Distrito de Imigração], janeiro de 1929, Washington, GPO, 1929, p. 4.

42 "Immigration Border Patrol" ["Patrulha de Imigração da Fronteira"], p.30. 
envolviam o patrulhamento de grandes extensões de território desabitado, longe do raio de visão da vigilância burocrática de Washington. ${ }^{43}$ A Patrulha de Fronteira funcionava em um ambiente de cada vez maior hostilidade racial contra os mexicanos; na verdade, suas atividades ajudaram a constituir aquele ambiente, prendendo de forma agressiva e deportando um número cada vez maior de mexicanos. A Guarda de Fronteira interrogava os trabalhadores mexicanos nas estradas e nas cidades, e não era raro "arrastões" prenderem várias centenas de imigrantes de uma só vez. No começo da década de 1930, o Serviço de Imigração estava prendendo cinco vezes mais suspeitos de serem estrangeiros ilegais na fronteira do México do que o fazia na área da fronteira canadense. O jornal de Los Angeles La Opinión acreditava que uma política agressiva de deportação resultaria em uma "desmexicanização do sul da Califórnia”. ${ }^{44}$

Ironicamente, os mexicanos se tornaram tão associados à imigração ilegal porque, ao contrário dos europeus, eles não estavam sujeitos a quotas numéricas e, ao contrário dos asiáticos, eles não eram excluídos como racialmente inelegíveis para a cidadania. Mas, à medida que a restrição numérica tornou-se primordial na política de imigração, seus aspectos repressivos - procedimentos de inspeção, deportação, a Guarda de Fronteira, processo criminal, e categorias irregulares de imigração - criaram muitos milhares de imigrantes ilegais mexicanos. O trabalhador mexicano sem documentação que cruzava a fronteira para trabalhar na indústria florescente da agricultura comercial surgiu como o estrangeiro ilegal prototípico.

\section{A reforma administrativa da lei e o desfazer dos estrangeiros ilegais}

Os estrangeiros ilegais deportados durante os últimos anos da década de 1920 e os primeiros anos da década de 1930 compreendiam tanto os que cruzavam a fronteira sem autorização e os que permaneciam além do tempo estipulado por seus vistos, como também aqueles que entravam legalmen-

\footnotetext{
${ }^{43}$ De acordo com Douglas Foley, o governo federal "deixou que a força de trabalho do sul resolvesse seus problemas com os Texas Rangers daquela localidade, com a Guarda da Fronteira e com os Anglo-Saxões hostis". Foley, From peones to politicos: class and ethnicity in a south Texas town, 1900-1987 [De Peones a Políticos: Classe e Etnicidade em uma Cidade do Sul do Texas], Austin, Tex., University of Texas Press, 1988, 1977, p. 18.

${ }^{44}$ Perkins, Border Patrol, p. 116; La Opinión, 29 de janeiro de 1929, p. 1 (traduzido do espanhol). Em 1932 o INS contou 3.812 prisões ao longo da fronteira com o Canadá e 19.072 prisões ao longo da fronteira com o México. Relatório Anual do INS, 1932, p. 44. O INS não relatou dados comparáveis a esses em anos anteriores.
} 
te, mas que cometiam uma ofensa sujeita à pena de deportação após sua entrada no país. Cada uma dessas categorias incluía imigrantes que já tinham se estabelecido no país e tinham emprego, propriedade e família. Esses imigrantes ilegais tinham, na verdade, se tornado membros da sociedade. Mas se sua inclusão na nação era uma realidade social, ela também era uma impossibilidade legal. Resolver essa contradição pela deportação causava miséria e sofrimento para esses imigrantes e suas famílias. Parecia a muitos como simplesmente injusto.

Testemunhando ante o Congresso, em 1934, Nicholas Grisanti, da Federação de Sociedades Italianas, em Buffalo, Nova Iorque, citou um caso típico de deportação injusta. Um imigrante italiano viveu a maior parte de sua vida em Buffalo. Ele era casado, com três filhos, e era bem empregado. Mas, Grisanti explicou, "em alguma época anterior, quando criança, ele tinha se apropriado de meio saco de carvão, dos trilhos da ferrovia, para manter sua família aquecida" e por esse crime fora condenado, recebendo uma sentença que fora suspensa. Anos mais tarde, ele foi ao Canadá para férias de verão. O Serviço de Imigração considerou seu retorno uma "nova entrada" e o deportou, com a justificativa de que ele tinha sido condenado por um crime envolvendo depravação moral, anterior ao "tempo de entrada". Sua deportação foi revogada depois que um protesto público levou o Governador em exercício de Nova York, Herbert Lehman, a perdoar sua "pequena ofensa". 45

Em certo sentido, o protesto contra deportações injustas surgiu do fato de que os imigrantes europeus e canadenses tinham que enfrentar um sistema que tinha se desenvolvido historicamente para justificar o tratamento arbitrário e sumário dos chineses e outros imigrantes asiáticos. Assim, durante a última parte da década de 1920 (e a primeira parte da década de 1930), surgiram críticos à política de deportação entre os advogados do bem-estar social e entre os reformadores legais. Esses reformadores não questionavam diretamente a deportação como uma prerrogativa do poder soberano da nação. Mas eles procuravam novas formas de conciliar imperativos conflitantes de soberania nacional com os direitos dos indivíduos. Durante a primeira parte da década de 1930, vários estudos legais pediam uma reforma da lei administrativa quanto à deportação. Estes incluíam Deportação de estrangeiros dos Estados Unidos para a Europa (Deportation of aliens from the U.S. to Europe), de Jane

\footnotetext{
${ }^{45}$ Senado dos EUA, Senado, Comitê sobre Imigração, "Deportação de Criminosos, Preservação das Unidades Familiares, Permissão de Estrangeiros Não Criminosos para Legalizarem seu Status", 74 Congresso, Segunda Sessão, 29 de fevereiro de 1934, p. 122.
} 
Perry Clark, um cientista político de Barnard, publicado em 1931; um relatório sobre a deportação pela Comissão Nacional sobre Obediência e Execução da Lei (Comissão Wickersham), publicado em 1931; e Controle administrativo dos estrangeiros: um estudo em lei administrativa e procedimentos (Administrative control of aliens: a study in administrative law and procedures), de William Van Vleck, diretor da Escola de Direito da Universidade George Washington, publicado em 1932, pelo Fundo da Commonwealth. Todos os três estudos baseavam suas descobertas no exame de casos reais de deportação e outros registros administrativos do Serviço de Imigração. ${ }^{46}$

Clark, Van Vleck e a Comissão Wickersham chegaram a essencialmente duas únicas conclusões gerais. Em primeiro lugar, eles acreditavam que a política de deportação era aplicada de forma arbitrária e desnecessariamente dura, resultando em grande sofrimento pessoal e na separação de famílias, sem nenhum benefício social. Em segundo lugar, em termos de procedimento, eles concluíram que a política de deportação freqüentemente operava nas brechas das estabelecidas tradições da jurisprudência anglo-saxã, especialmente as que lidavam com revisão judicial e processo devido. Como Lucy Salyer mostrou, durante a última parte do século XIX e a primeira parte do século XX, as cortes federais geralmente confirmavam o caráter sumário dos procedimentos de imigração. Até os anos 20 do século XX, os estrangeiros só tinham ganho alguns direitos processuais, entre eles o direito a uma audiência administrativa e o direito de ter um advogado nessa audiência. ${ }^{47}$ Mas os críticos consideravam que até mesmo esses direitos eram conspurcados ou sofriam da falta de outras salvaguardas processuais e citavam um amplo espectro de abusos.

Especificamente, os críticos argumentavam, os estrangeiros eram freqüentemente "detidos à força". Os Comitês de Averiguação Especial (Boards of Special Inquiry), que conduziam audiências formais de deportação, eram freqüentemente tribunais de uma só pessoa, com o inspetor de imigração sendo simultaneamente o oficial que efetuou a prisão, o promotor e o juiz. ${ }^{48}$

\footnotetext{
${ }^{46}$ Jane Perry Clark, Deportação de Estrangeiros; Comissão Nacional dos EUA sobre Obediência e Vigilância da Lei, Relatório sobre a Vigilancia das Leis de Deportação dos Estados Unidos, Washington, 1931 (de agora em diante "Relatório Wickersham"); William Van Vleck, Administrative Control [Controle Admininstrativo].

${ }^{47}$ Lucy Salyer, Laws harsh as tigers: chinese immigrants and the shaping of Modern Immigration Law [Leis ferozes como tigres: imigrantes chineses e a formação da Moderna Lei de Imigração, Chapel Hill, University of North Carolina Press, 1995, p. 172-183; Japanese immigrant case [Caso do imigrante japonês] (Yamata v. Fisher), 189 US 86 (1903).

${ }^{48}$ Van Vleck, Administrative Control [Controle Admininstrativo], 26, p. 90-95; Wickersham Report [Relatório Wickersham], 65, p. 157-158, 170-171.
} 
Os Comitês operavam sem regras de evidência, prontamente acolhendo boatos, opiniões, as cartas anônimas, bem como "informação confidencial". O estrangeiro devia também apresentar prova "para mostrar a razão... por que ele não deveria ser deportado". Um estudo descobriu que somente um sexto dos estrangeiros em procedimentos de deportação tinham representação legal, chegando a um a dois por cento ao longo da fronteira mexicana e a até 20 por cento na cidade de Nova Iorque. ${ }^{49}$

Além disso, o Serviço de Imigração interpretava o estatuto de uma forma que ampliava grosseiramente os termos da lei para justificar a deportação. O maior abuso estava na aplicação da provisão "passível de tornar-se um peso público na época da entrada", ou "LPC" (da sigla em inglês), que, segundo Clark, "foi amplamente aplicada em casos de deportação". O Serviço de Imigração deportou imigrantes que cometeram crimes menores ou violaram normas de moralidade sexual, como ter filhos fora do casamento, que não eram ofensas passíveis de deportação, com a justificativa de que eram "LPCs antes da entrada”. Em outras palavras, o Serviço de Imigração considerava deslizes ou azar subseqüente à entrada como o resultado teleológico de uma condição prévia, que aduzia por meio de julgamento retroativo. ${ }^{50}$

Finalmente, os imigrantes sob mandados de deportação, tinham poucas possibilidades de apelo. O Comitê de Revisão do Departamento de Trabalho (Labor Department's Board of Review), que fazia recomendações à Secretaria de Trabalho, não tinha autoridade estatutária. A revisão judicial era extremamente rara, já que as cortes federais se continham bastante em casos de imigração, tendo progressivamente limitado os motivos de revisão judicial em casos de exclusão de chineses durante os anos anteriores. E durante toda a década seguinte, as cortes julgaram menos de 300 chamados a juízo de habeas corpus em casos de deportação e julgaram quase 70 por cento deles a favor do Serviço de Imigração. ${ }^{51}$

A crítica legal da política de deportação revelou as preocupações do realismo legal durante os anos entre as duas guerras mundiais: uma rejeição da discussão de categorias e um desejo de transformar as diferenças tipológicas

${ }^{49}$ Van Vleck, Administrative Control [Controle Admininstrativo], p. 99-100, 107; Clark, Deportation of aliens [Deportação de Estrangeiros], p. 324; Kohler, Immigration and aliens [Imigração e estrangeiros], p. 413; Wickersham Report [Relatório Wickersham], p. 107-108.

${ }^{50}$ Clark, Deportation of aliens [Deportação de estrangeiros], p. 309; Van Vleck, Administrative control [Controle Administrativo], p. 97-98, 119-125.

${ }^{51}$ Relatório Anual do INS, 1928-1932; Secretário do Trabalho, Relatório Anual, 1933-1936. 
em diferenças de grau; a prioridade da experiência em relação à lógica formal; e, conseqüentemente, uma crença na necessidade de discrição administrativa do estado regulatório emergente. ${ }^{52}$ Segundo os críticos legais, a política de deportação parecia um problema legal que saiu do controle, surgindo talvez menos da política do que da administração da lei, baseada em categorias rígidas, que não admitiam flexibilidade ou espaço para experiência. Porquanto a principal corrente de críticas se relacionasse a problemas processuais e de aplicação, a reforma administrativa da lei concedia uma maneira alternativa e menos controversa de reforma da política de deportação do que a tentativa mais abertamente política adotada pelos militantes do bem-estar social liberal e pelos advogados defensores da imigração. Esses últimos tinham poucos amigos no Congresso durante a Depressão, quando o trabalho era escasso e havia chamadas renovadas para restrição às entradas de imigrantes e para mais deportações. Na verdade, os olhos dos reformadores administrativos da lei estavam voltados não tanto para o Congresso, mas para o judiciário, onde eles acreditavam que se poderia alcançar progressos, definindo mais claramente os limites do poder executivo em matérias de deportação. ${ }^{53}$

Apesar disso, embutida nos argumentos para uma reforma administrativa da lei, havia uma poderosa crítica política. Essa crítica desafiava as premissas eugênicas da política de imigração, isto é, a idéia de que a não desejabilidade social derivava de deficiências de caráter inato, que eram percebidas como biologicamente enraizadas na raça, gênero, ou "sangue ruim". Em certo sentido, a reforma administrativa da lei era um pretexto para um desafio cultural mais amplo aos políticos nativistas, questionando, em particular, as teorias do final do século XIX e começo do século XX sobre a degenerescência social e, mais especificamente, as idéias sobre os papéis de gêneros, moralidade sexual e crime. Esses padrões normativos de desejabilidade social e aptidão moral para a cidadania continuaram a definir os padrões qualitativos para a admissão e a deportação de imigrantes no Ato de Imigração de 1924, mesmo quando foram parcialmente ofuscados pela nova ênfase da lei em restrições numéricas. No final das décadas de 1920 e de 1930, os críticos legais desafiaram a aplicação desses padrões qualitativos em casos de deportação.

52 Morton Horwitz, The transformation of american law: the critique of legal orthodoxy [A transformação da lei americana: a crítica da ortodoxia legal], 1870-1960, New York, Oxford University Press, 1992, p. 189, 199.

53 The Nation [A Nação], 29 de abril de 1931, p. 463; Nota, "Statutory Constructionin Deportation Cases" ["Construção Estatutária em Casos de Deportação"], Yale Law Journal, 40, 1931, p. 1283. 
Durante esse período, as cortes só fizeram pequenos ajustes à lei de deportação. Elas esclareceram que a condenação a um crime "antes da entrada" se referia a crimes cometidos fora dos Estados Unidos antes da primeira entrada do imigrante no país. Outros casos eliminavam a má conduta criminal da categoria de acusação pública, de acordo com o julgamento do Juiz Learned Hand de que a acusação pública sugeria "dependência e delinqüência" e que a LPC não deveria ser usada para deportar pessoas por crimes menores que não fossem ofensas passíveis de deportação. ${ }^{54}$

O apelo para evitar a separação familiar foi particularmente eficiente nas áreas onde os imigrantes europeus eram numerosos e tinha alguma influência política. Em Nova York, muitos réus condenados recebiam perdões executivos depois que serviam seu tempo de prisão, para evitar sua deportação. O governador Herbert Lehman concedeu 100 perdões desse tipo durante sua gestão administrativa. ${ }^{55}$

Embora perdões executivos e decisões de cortes federais lidassem com alguns dos problemas da política de deportação, isso ficava aquém do estabelecimento de uma política nacional uniforme. No começo da década de 1930, o Serviço de Imigração se mostrou resistente à idéia de que devesse livrar as famílias dos estrangeiros da "miséria de serem separados", citando seu "mero dever de livrar o país desses visitantes não desejados que 'entraram de penetra". ${ }^{56}$

Em 1933 e 1934, os liberais adotaram uma nova estratégia legislativa para a reforma da imigração, que se processou simultaneamente por dois caminhos: um que propunha impor sanções ainda mais severas aos criminosos e uma que propunha evitar a separação de famílias em casos que fossem "excepcionalmente meritórios". A legislação introduzida em 1933 e 1934 unia as duas questões em um único projeto de lei. Esta estratégia deu aos reformadores cobertura política para demonstrarem seu engajamento na restrição à imigração e contra os criminosos, enquanto defendia a compaixão para "pessoas relativamente inofensivas e merecedoras". ${ }^{57}$

${ }^{54}$ Browne v. Zubrick, 45 F (2º 931 (CAA 6º 1930); Iorio v. Day, 34 F. $2^{\circ} 920$ (CAA 2º 1929); ver também Lisotta v. EUA, 3 F (2) 108 (CAA 5 1924); EUA ex rel. Klonis v. Davis, 13 Fed. (2) 630 (CAA $2^{\circ}$ 1926).

55 "Pardons and Commutations", Public Papers of Governor Herbert S. Lehman, 1933-1942 ["Perdões e Comutações", Artigos Públicos do Governador Herbert S. Leman, 1933-1942].

${ }^{56}$ Relatório Anual do INS, 1931, p. 13-14.

${ }^{57}$ Secretary of Labor, Annual Report [Secretário de Trabalho, Relatório Anual], 1934, p. 53. 
Decidir quem eram os criminosos e quem eram os merecedores, no entanto, estava em discussão. Desde a era Progressiva, o relativismo e o ambientalismo tinham ficado cada vez mais influentes no pensamento sobre desvio criminoso e moral. Havia também maior apoio social à idéia de que as pessoas que cometiam erros podiam se regenerar. Falando contra a lei de 1929, que impedia para sempre o reingresso depois da deportação, Jane Addams observou: "tornar um velho erro indelével - matar a possibilidade de redenção no futuro, é sempre um valor duvidoso". Assim, crimes menores e transgressões sexuais, que já haviam servido de evidência para a deficiência inerente do caráter, agora podiam ser consideradas "[ofensas] mais ou menos inocentes contra a lei de imigração", caindo abaixo da marca definida para a deportação. ${ }^{58}$

O discurso referente à deportação injusta se referia principalmente aos imigrantes europeus e somente raramente aos mexicanos. Os mexicanos étnicos nos Estados Unidos expressaram as mesmas preocupações que os europeus; por exemplo, o jornal de língua hispânica La Opinión criticava a deportação de mexicanos que tivessem mais de dez anos de residência nos Estados Unidos, que tivessem negócios e que tivessem família. ${ }^{59}$ Mas os mexicanos continuavam marginalizados do discurso hegemônico da imigração. Além disso, os reformistas euro-americanos pediam leniência em casos de crimes, mas não em casos de entrada ilegal no país, porque esse era um componente principal do sistema baseado em restrição de números de entradas, aos quais eles não se opuseram jamais.Em contraste com as idéias relativistas e ambientalistas de crime, a idéia de transgredir o espaço soberano da nação se sobressaía como uma ofensa absoluta. Sendo assim, enquanto que os imigrantes europeus com fichas criminais podiam ser considerados "merecedores", os mexicanos que eram pegos sem os documentos corretos tinham pouca chance de escapar, tanto do estigma de criminalização quanto do destino da deportação.

As reformas legislativa e administrativa operavam de forma que aumentavam a disparidade racial em práticas de deportação. Em 1929, o Congresso aprovou o Ato de Registro, que legalizava o status de "estrangeiros honestos, obedientes à lei, que podem estar no país sob alguma irregularidade meramente técnica". A lei permitia que os imigrantes se registrassem como residentes

${ }^{58}$ Morton Keller, Regulating a new society: public policy and social change in America, 19001933 [Regulando uma nova sociedade: política pública e mudança social na América, 1900-1933], Cambridge, Mass., 1994, capítulos 3-4; Addams citado em Survey, 15 de julho, 1930, p. 347; Interpreter, abril 1929, p. 76.

59 "Frequent Deportation of Mexicans" ["Freqüente Deportação de Mexicanos"], La Opinión, 30 de janeiro de 1929, p. 2 (traduzido do espanhol). 
permanentes por uma taxa de vinte dólares, se pudessem provar que residiam continuamente no país desde 1921 e que tinham bom caráter moral. ${ }^{60} \mathrm{~A}$ lei não favorecia formalmente os europeus em detrimento dos mexicanos. Mas, dos 115.000 imigrantes que registraram suas entradas anteriores no país entre 1930 e 1940, oitenta por cento eram europeus ou canadenses. ${ }^{61}$

Durante os anos 30 e 40, o Departamento de Trabalho instituiu uma série de reformas que objetivavam, ainda que de forma limitada, questões do processo devido (due process) em procedimentos de deportação e estabelecia mecanismos administrativos pelos quais certos estrangeiros ilegais a maioria deles europeus - podiam legalizar seu status. Defensores da reforma administrativa e da lei de imigração apoiaram a administração de Franklin D. Roosevelt, em 1933. O Secretário de Trabalho de Roosevelt, Frances Perkins, era um reformista da Era Progressista de Nova Iorque. ${ }^{62}$ Em 1934, Perkins e seu comissário de imigração, DW MacCormack instituíram uma série de reformas administrativas no INS (Serviço de Imigração e Naturalização). Uma das linhas de reforma se referia a procedimentos e processo devido (due process). O INS terminou com a prática de prender estrangeiros suspeitos sem mandado, em lugares distantes do tempo e lugar de entrada. Também determinou que o mesmo funcionário não podia conduzir o exame preliminar e a audiência final. ${ }^{63}$

Um segundo tipo de reforma se referia ao uso da discrição administrativa para livrar da deportação estrangeiros para quem a deportação causaria sofrimento. MacCormack fez lobby no Congresso para permitir possível suspensão de deportação em casos "meritórios" ${ }^{64}$ Mas a ação do Congresso só viria lentamente. Embora os Democratas agora controlassem o Congresso, a ala sul

${ }^{60}$ Relatório Anual do INS, p. 12-13; Ato de 2 de março, 1929 (45 Stat 1551).

${ }^{61}$ Relatório Anual do INS, 1930-1932; Secretário do Trabalho, Relatório Anual, 1933-1940; Paul S. Taylor, "Mexican labor in the US: Dimmit County, Winter Garden District" ["Trabalho Mexicano nos EUA: Dimmit County, Winter Garden District, Sul do Texas"], Univ. of California Publications in Economics [Publicaçôes em Economia da Universidade da Califórnia], 6, 1930 , p. 322.

${ }^{62}$ Sobre Perkins, ver George Martin, Madam Secretary: Frances Perkins [Senhora Secretária: Frances Perkins], Boston, Houghton Mifflin, 1976.

${ }^{63}$ Secretário do Trabalho, Relatório Anual, 1934, p. 50-52.

${ }^{64}$ DW MacCormack, "Memorandum of the Commissioner of Immigration and Naturalization to the Committee on Immigration of the Senate and the Committee of Immigration and Naturalization of the House of Representatives, relative to certain proposed changes in the Immigration Law" ["Memorando do Comissário de Imigração e Naturalização ao Comitê de Imigração do Senado e ao Comitê de Imigração e Naturalização da Casa de Representantes, relativo a certas mudanças propostas na Lei de Imigração"], 24 de abril de 1934, p. 2; Senado dos EUA, Comitê de Imigração, "Deportation of criminals, preservation of family units, permit noncriminal aliens to legalize their status" ["Deportação de criminosos, preservação das unidades familiares, permissão para estrangeiros não criminosos legalizarem seu status”], $74^{\circ}$ Congresso, $2^{\mathrm{a}}$ sessão, 24 de fev., 29, 3 de março, 11, 1934, p. 16, 198. 
do partido servia como uma barreira conservadora à reforma em questões de imigração. No contexto da emergência econômica imposta pela Depressão, a reforma da imigração não era alta prioridade no rol de reformas legislativas de Roosevelt. Sem reforma estatutária, Perkins e MacCormack, de forma bem criativa, usaram provisões da lei vigente para suspender deportações e legalizar o status de certos imigrantes ilegais em casos de sofrimento. Isso envolvia um procedimento em duas etapas, pelo qual o Secretário de Imigração concedia ao estrangeiro ilegal uma suspensão temporária de deportação e o permitia partir para o Canadá e reingressar nos Estados Unidos como um residente legal permanente.

O Secretário de Imigração fornecia essas suspensões invocando uma cláusula obscura do Ato de Imigração de 1917, a Sétima Provisão à Seção 3, que estipulava que "os estrangeiros, retornando depois de ausência temporária de sete anos consecutivos para um domicílio não abandonado nos Estados Unidos, podem ser admitidos à discrição do Procurador Geral e sob certas condições conforme o desejo deste". O Congresso queria a Sétima Provisão como uma medida para estrangeiros que estivessem temporariamente fora do país quando o Ato de Imigração de 1917 foi aprovado e que, por razões freqüentemente de natureza técnica, eram passíveis de expulsão ao retornarem. ${ }^{65} \mathrm{~A}$ inovação de Perkins foi a de usar o conceito "retornando após uma ausência temporária” para aplicar a estrangeiros que ainda não tinham saído do país e incluir em seu escopo estrangeiros ilegais que "tinha vivido nos EUA muito tempo". Invocando a Sétima Provisão para evitar deportações, Perkins retomou o princípio central da política de imigração anterior a 1924, inerente ao estatuto de limitação da deportação, qual seja, a idéia de que os imigrantes que se estabeleceram no país não deveriam ser expulsos. ${ }^{66}$

O processo de reajuste do status ficou conhecido como um procedimento de "pré-exame". Desde 1933 o INS tinha assegurado cartas de permissão para os estrangeiros legais que iam ao Canadá em visitas curtas, assegurando-lhes o reingresso, desde que eles fossem primeiramente examinados e fossem julgados admissíveis pelos inspetores da imigração. Isso começou como um gesto

${ }^{65}$ Ato de Imigração de 1917 (39 Stat 874). O ato de 1917 incluía a provisão 17, ou exceções, às regras de exclusão da lei. Ver Relatório do Senado 352, 64 Congr., $1^{\text {a }}$. sessão, p. 6, sobre a Sétima Provisão como uma cláusula de sofrimento. Ver também Carta, Frances Perkins para o Repr. Dave Batterfield Jr., 17 de set., 1940, arquivo Imigração, Geral, 1940, caixa 66, Arquivos do Assunto Geral do Secretário, Registros do Depto. de Trabalho, RG 174, Arquivo Nacional (College Park) (de agora em diante "Artigos Perkins").

${ }^{66}$ Perkins para Batterfield; Memorando, Procurador Geral para Rufus Holman, 4 de jan., p. 4, arquivo 55819/402D, caixa 75 , acesso $58^{\text {a }} 734$, INS. 
de cortesia que permitia que os estrangeiros legais não precisassem solicitar uma permissão formal de reingresso. As autoridades canadenses também exigiam uma garantia por escrito de que os visitantes não permaneceriam no Canadá. A prática tornou-se conhecida na linguagem peculiar do INS como "pré-exame" - isto é, inspeção para readmissão antes da partida. ${ }^{67}$

Em 1935, o pré-exame se estendeu aos imigrantes ilegais para facilitar sua legalização. Um acordo formal entre o Departamento de Estado dos Estados Unidos, o Serviço de Imigração e seus correspondentes canadenses detalhou procedimentos pelos quais um imigrante, nos Estados Unidos, sem um visto, poderia ser "pré-examinado" para admissão legal, sair do país como uma "partida voluntária", ir ao mais próximo cônsul americano no Canadá, obter um visto para residência permanente, e reingressar nos Estados Unidos formalmente com uma admissão legal. O INS suspendeu assim a territorialidade do Estado para desfazer o status ilegal de certos imigrantes.$^{68} \mathrm{O}$ programa de pré-exame foi inicialmente pensado para os imigrantes que tinham um(a) esposo/a que era cidadão(dã) americano(a) ou filhos e cujo status ilegal resultava de um erro técnico. Este era um raciocínio político inquestionável no qual evitar sofrimento para os cidadãos equivalia a negar deportação em casos triviais. Mas "sofrimento" mostrou-se um conceito elástico, uma outra versão da noção de "merecedor". Foi rapidamente ampliado para certos tipos de casos criminais, ou, mais precisamente, para certos criminosos. Um caso típico envolveu Mrs. Lillian Joann Flake, que foi acusada de roubo, em 1918 e 1922, e apropriação indébita (roubo em lojas), em 1930. Canadense, ela viveu nos Estados Unidos mais de dezessete anos e tinha um marido e filha em Chicago. Em um outro caso, o INS manifestou-se em nome de Carlos Reali, um italiano, "em vista do fato de que o estrangeiro é casado com uma cidadã dos Estados Unidos e que tem três crianças nascidas americanas". Sua ficha, acrescentou o INS, era boa, mesmo levando-se em consideração que ele obtivera um visto com fraude e perjúrio, em 1924. O INS revogou as ordens de

${ }^{67}$ Memorando, AM Doig, Diretor do Distrito de Detroit Interino para o Comissário Geral, 7 de set., 1933; MacCormack para os Diretores do Distrito, Newport [Vt], Buffalo, NY, Detroit, Grand Forks [ND] e Seattle, 18 de dez., 1933, arquivo 55819/402, caixa 75, accesso 58A734, INS. Pré-exame como descrito aqui é diferente da política de "pré-inspeção" do INS, que se refere à inspeção no exterior, antes da emigração.

68 Departamento de Imigração e Colonização [Canadá], Circular Oficial n. 31, 23 de fevereiro de 1935; MacCormack para AL Jolliffee, Comissário de Imigração [Canadá], 21 de outubro de 1935, arquivo 55819/402, INS. O pré-exame acabou sendo incorporado ao Código Federal. Ver 8 CFR pt. 142. 
deportação de Flake, Reali e centenas de outros, permitindo que eles saíssem do país voluntariamente e obtivessem um visto legal para readmissão. ${ }^{69}$

Significativamente, no entanto, o privilégio de pré-exame ficou restrito aos imigrantes europeus. Os asiáticos não se qualificavam, porque eles eram categoricamente excluídos da imigração, por motivos de inelegibilidade racial. ${ }^{70}$ Os mexicanos não foram inicialmente excluídos, mas, após um forte protesto do Cônsul dos Estados Unidos em Juarez, o Serviço de Imigração abandonou o programa para os mexicanos. ${ }^{71}$ Esse esclareceu que o "procedimento geral de pré-exame está limitado a certos estrangeiros - parentes dos cidadãos americanos - desejando ir ao Canadá" (ênfase no original). Documentos posteriores chamam a atenção pelo fato de se referirem ao programa como o "procedimento de pré-exame canadense". Assim, inicialmente, os mexicanos não foram excluídos explicitamente, mas por uma falta de vizinhança, pela sua distância do Canadá, onde a partida física e o reingresso eram feitos. Em 1945, o INS explicitamente restringiu o pré-exame para "qualquer outro que não um cidadão do Canadá, do México, ou de quaisquer das ilhas adjacentes aos Estados Unidos”. Esta política parecia ser neutra quanto à raça, por se aplicar a todos os países com fronteiras contíguas com os Estados Unidos, mas na verdade ela foi feita com o propósito de negar categoricamente acesso a migrantes mexicanos e caribenhos. Porque o pré-exame envolvia a permissão para uma entrada temporária no Canadá para se obter um visto americano, ele era irrelevante para os canadenses, que não precisavam de qualquer permissão especial para entrar no Canadá. ${ }^{72} \mathrm{O}$ racismo da política era profundo, pois negava, a priori, que a deportação podia causar sofrimento para as famílias

${ }^{69}$ Carta, James Houghterling para o Senador James Lewis, 20 de abril de 1938, arquivo 55819/402B, caixa 75, acesso 58A734, INS; IF Wixon para o Secretário de Estado, 8 de novembro de 1937, arquivo 55819/402A, ibidem.

${ }^{70}$ Parece que Perkins quis ajudar os asiáticos, mas a lei atava-lhe as mãos. Por exemplo, ver o caso de Ramkrishana Sakharan Jovotode, em carta, Perkins para Josephus Daniels, 22 de abril de 1940, arquivo Imigração-Deportação, 1940, caixa 67, artigos de Perkins.

${ }^{71}$ MacCormack morreu de repente, em 1937. É possível que, se ele tivesse vivido, tivesse lutado por uma aplicação universal do programa de pré-exame, embora, é lógico, não possamos saber ao certo.

72 GC Wilmoth para todos os inspetores encarregados e inspetores chefes de guarda, El Paso District (rascunho) [1938], arquivo 55819/402C; formulário de aplicação formal [1942] e Parte 412 dos Regulamentos de Imigração, 1943, arquivo 55819/402D; Ugo Carusi para Tom Clark, 15 de outubro de 1945, ibidem; Senado dos EUA, Relatório de Comitê do Judiciário, "Immigration and Naturalization Systems of the US" ["Sistemas de Imigração e Naturalização dos EUA"] 81 ${ }^{\circ}$ Congresso, 2 $2^{a}$ sessão, Relatório do Senado 1515, 20 de abril de 1950 (de agora em diante "Relatório do Senado 1515"), p. 604. 
de não-europeus. Além disso, ao enfatizar os valores familiares, a política reconhecia somente um tipo de família, o núcleo familiar intacto residente nos Estados Unidos, e ignorava famílias transnacionais. Ele deixava de reconhecer que muitos migrantes do sexo masculino sem documentação que vieram para os Estados Unidos sozinhos, na verdade, mantinham núcleos familiares em seus países de origem e que o envio de dinheiro por parte do migrante era um outro tipo de estratégia para a subsistência familiar.

Além do pré-exame, o INS começou a suspender ordens de deportação - uma vez mais, majoritariamente, para europeus - depois de 1940, quando o Congresso deu ao Procurador Geral autoridade para dar perdão discricionário em troca de registro de estrangeiro, que tinha sido há muito tempo negado, mas que passou como uma medida da época da guerra. A lei de 1940 permitia a suspensão da deportação em casos envolvendo estrangeiros de bom caráter moral, se a deportação fosse resultar em "sérias dificuldades econômicas" para a família imediata do estrangeiro. ${ }^{73}$

Em geral, a despeito de várias reformas, a mudança era limitada e lenta. Alívio discricionário da deportação incorporou-se à lei de imigração no Ato de Imigração e Naturalização de 1952. ${ }^{74}$ Mas, durante toda a década de 1950 e início da década de 1960, quase nenhum progresso foi feito em termos de justo processo e de revisão judicial.

\section{Conclusão}

A restrição numérica de imigrantes, aprovada na década de 1920, substituiu razões qualitativas para a inclusão ou exclusão por critérios que eram ao mesmo tempo mais abstratos e arbitrários - o programa de quota e o visto propriamente dito. Anteriormente, a territorialidade tinha sido invocada para excluir pessoas consideradas não aptas a fazer parte da nação. Nos anos 20, normas qualitativas de desejabilidade permaneceram na lei como razões para a inclusão e a expulsão, mas, como vimos, elas eram aplicadas de modo irregular em casos de deportação menos freqüentemente do que a regra da documentação e, além disso, elas eram aplicadas com considerável discrição. À medida

${ }^{73}$ Ato de 28 de junho de 1940 (54 Sta. 670). Para discussão sobre o "bom caráter moral" na suspensão de casos de deportação, ver Relatório do Senado 1515, p. 596.

${ }^{74}$ Os termos básicos da Sétima Provisão foram incorporados à Seção 212(c) do Ato de Imigração e Naturalização de 1952, 66 Sta 163. Manteve-se na lei até 1996, quando foi eliminado. Suspensão de deportação foi incorporada à Seção 244(a) do INA. Permanece na lei, embora os motivos sejam agora bem restritos. 
que as normas qualitativas perdiam importância, a territorialidade - definindo e policiando o espaço nacional - tornou-se tanto o meio como o fim da política de imigração.

No entanto, os americanos passaram a acreditar, cada vez mais, que a deportação, inicialmente imaginada para as classes desprezadas e perigosas, era não democrática e injusta quando aplicada a imigrantes comuns, com residência e família nos Estados Unidos. Portanto, durante a década de 1930 e os primeiros anos da década de 1940, reformas estatutárias e administrativas tentaram diminuir a tensão entre soberania e democracia que a política de imigração tinha criado. Os valores de família e as visões ambientalistas de delinqüência e moralidade prepararam o caminho para a reforma, enquanto que a raça determinou seu alcance.

Assim, tornou-se possível reverter a ilegalidade dos imigrantes ilegais italianos, poloneses, e outros europeus, pelo poder da discrição administrativa. Logicamente, nem todos os imigrantes europeus foram legalizados, mas uma estimativa sugere que, entre 1925 e 1965, cerca de 200.000 imigrantes ilegais europeus foram considerados como merecedores da legalização de seu status, sob o Ato de Registro (Registry Act), pelo pré-exame, ou pela suspensão de deportação. ${ }^{75} \mathrm{O}$ reconhecimento formal de sua inclusão na nação criou o fundamento mínimo exigido para adquirir a cidadania e contribuiu para que acontecesse uma reforma mais ampla da identidade racial, um processo que transformou as "raças menores da Europa" em americanos brancos étnicos.

Em contraste, caminhar (ou nadar) através da fronteira tornou-se o ato quintessencial da imigração ilegal, o ponto mais extremo em uma ordem relativista de imigração ilegal. O método de entrada dos mexicanos ilegais podia assim ser percebido como "criminoso" e os imigrantes ilegais não merecedores de perdão. Combinado com a construção dos mexicanos como trabalhadores agrícolas migrantes (tanto legais como ilegais), nos anos 40 e 50 do século XX, essa percepção deu grande força à noção de que os mexicanos não tinham direito à presença no território dos Estados Unidos, não tinham o direito de reivindicar o pertencimento.

\footnotetext{
75 Ver Matthew Jacobson, Whiteness of a different color [Branqueza de uma cor diferente], Cambridge, Mass., Harvard University Press, 1998; James Barrett e David Roediger, "In-between people: race, nationality and the 'new immigrant' working class" ["Intermediários: raça, nacionalidade, e a classe de trabalhadores 'novos imigrantes"'] Journal of American Ethnic History, 16:3, Spring, 1997, p. 3-44; Ian Haney-Lopez, White by law: the legal construction of race [Branco por lei: a construção legal da raça], New York, New York University Press, 1995.
} 
O princípio básico da doutrina da lei de imigração que privilegiou o poder absoluto do Congresso sobre os direitos individuais dos imigrantes permaneceu intacto. A contradição entre soberania e direitos individuais foi resolvida somente na medida em que o poder da discrição administrativa fez poucas exceções da regra soberana. No contexto da lei da imigração que privilegiou a territorialidade e o controle da fronteira, e nas mãos de funcionários da imigração, operando em meio a políticas e preconceitos sociais de seu tempo, essa discrição serviu para racializar o espectro do estrangeiro ilegal. 